\title{
Lubricity and Tribological Properties of Dicarboxylic Acid and Oleyl Alcohol Based Esters
}

\author{
(Sifat Pelinciran dan Tribologi Ester Berasaskan Asid Dikarboksilik dan Alkohol Oleil)
}

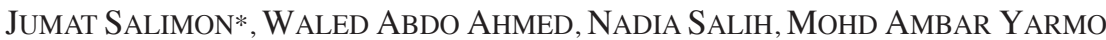 \\ \& DARFIZZI DERAWI
}

\begin{abstract}
Synthesis of new lubricants nowadays is increasing to improve the lubricity properties and the quality of lubricant. In the current study, eight diesters with different chemical structures were tested in terms of their suitability as lubricants. The esterification reaction was carried out using Dean-Stark distillation method with some modification. Fourier transformation infra-red (FTIR), proton and carbon nuclear magnetic resonance $\left({ }^{1} \mathrm{H}\right.$-NMR and ${ }^{13} \mathrm{C}$-NMR), were used to verify the chemical structure of the diesters. The results showed that the dioleyl pimelate (DOlP), dioleyl adipate (DOlA), dioleyl glutarate (DOlG), and dioleyl succinate (DOlSuc) showed good low temperature properties with pour point values at $-10,-12,-16$ and $-20^{\circ} \mathrm{C}$, respectively. The dioleyl dodecanedioate (DOlD) indicated remarkable flash point value at $305^{\circ} \mathrm{C}$ and had slightly high oxidative stability temperature $\left(\right.$ OT) at $183^{\circ} \mathrm{C}$. The flash point increased with the number of carbons for dicarboxylic acid used, while oxidative stability was affected by the unsaturated of oleyl alcohol. Tribological study showed that the diesters were non-Newtonian except DOID, which was Newtonian fluid. All the diesters were found to be boundary lubricants with low coefficients of friction (COF). Overall, the results indicated that all the diesters studied can be used as lubricating base oils.
\end{abstract}

Keywords: Coefficients of friction; flash point; oxidative stability; pour point; tribological properties

\section{ABSTRAK}

Sintesis pelincir pada masa ini telah meningkat untuk menambahbaik sifat pelinciran dan kualiti sesuatu minyak pelincir. Dalam kajian ini, lapan jenis ester berlainan struktur kimia telah diuji kesetabilannya untuk kegunaan pelincir. Tindak balas pengesteran telah dilakukkan dengan menggunakan penyulingan Dean-Stark dengan sedikit pengubahsuian. Struktur kimia diester terhasil dibuktikan dengan menggunakan transformasi Fourier inframerah (FTIR), nuklear magnetik resonan proton dan karbon $\left({ }^{1} H\right.$-NMR dan ${ }^{13} C$-NMR). Hasil kajian menunjukkan dioleil pimelat (DOlP), dioleil adipat (DOlA), dioleil glutarat (DOlG) dan dioleil suksinat (DOlSuc) mempunyai sifat suhu rendah yang baik dengan nilai takat tuang masing-masing pada -10, $-12,-16$ dan $-20^{\circ} \mathrm{C}$. Dioleil dodekanedioat (DOID) pula menunjukkan nilai takat kilat yang tinggi pada $305^{\circ} \mathrm{C}$ dan mempunyai kestabilan oksidatif( OT) yang agak tinggi pada $183^{\circ} \mathrm{C}$. Takat kilat ester meningkat dengan peningkatan bilangan karbon asid dikarboksilik yang digunakan, sementara kestabilan oksidatif dipengaruhi oleh ketaktepuan alkohol oleil. Kajian tribologi menunjukkan diester yang terhasil bersifat bukan-Newtonian kecuali DOlD, yang bersifat bendalir Newtonian. Kesemua diester menunjukkan sifat pelincir sempadan dengan pekali geseran (COF) yang rendah. Secara keseluruhannya, hasil kajian menunjukkan kesemua diester kajian boleh digunakan sebagai minyak asas pelincir.

Kata kunci: Kestabilan oksidatif; pekali geseran; sifat tribologi; takat kilat; takat tuang

\section{INTRODUCTION}

There is an increasing use of synthetic esters as base fluids for lubricants in applications. This is due to the performance advantage offered by the properties of the over mineral oils. The functional group in esters carries a molecular dipole, thus ester lubricants have higher polarity than mineral oils. It is possible to have a more precise control over the chemical structure of ester lubricants can be controlled more precisely than the chemical structure of mineral oils. This is due to the fact that ester lubricants are generated by chemical synthesis from controlled raw materials (Boyde 2005). Moreover, their ester base fluids have been reported to be highly affinite for metal surfaces. This feature is attributed to the high polarity of dicarboxylic acid. In comparing dicarboxylic acid ester to mineral oils or Polyalphaolefins (PAOs) of comparable viscosity, the first one typically provides lower friction and lower wear under boundary lubrication conditions than the second. Dicarboxylic acids ester which mainly contains linear acid or alcohol groups is capable of forming a more coherent, tightly packed surface film than branched group. Therefore, it has superior lubricity to esters which mainly contain branched groups (Rudnick 2006). 
Previous research reported widespread applications of some esters of dicarboxylic acids. Such applications include adipic and sebacic acid esters. They have been used as high-quality synthetic oils for over 50 years (El-Magly et al. 1990). Oils which are generated from dicarboxylic acid esters are characterised by a low pour point, good oxidative stability, high flash point and good tribological and rheology properties. Within the increasing temperature, their viscosity gets slightly reduced. The result, their viscosity indexes are high (Rudnick 2006). The physical properties can be primarily attributed to the structure of the lubricant base stock. For the occurrence of the chemical properties of the finished or formulated lubricants, they occur as a result of using the additives with the base stock. Thus, the selected properties of interest are viscosity, surface tension, thermal properties, volatility, oxidative stability, thermal stability, hydrolytic stability, gas solubility, and inflammability (Bhushan 2013).

Oleyl alcohol was used as an antifoam agent and cutting lubricant (Lee et al. 2003; Sudimack et al. 2002). Methyl oleate ester melts at $-20^{\circ} \mathrm{C}$ has fairly good oxidative stable. Such properties imply the suitability of oleate esters as candidates for biolubricants (Fatemi \& Hammond 1980). There are variety of esters which used in neat oils. These include esters such as monoesters (methyl oleate or isopropyl palmitate), diesters (propylene glycol dioleate) and polyol esters (trimethylolpropane trioleate). They are also used as base oils, which is usually the result of some additional requirements including higher lubricity, minimizing misting or a desire for a high level of biodegradability. Friction modifiers for automotive applications include some carboxylic acids, sulfurized fatty acids, glycerol monoesters and oleate esters (Rudnick 2006). Among synthetic esters is the TMP trioleate which is recognized as very useful, and its usefulness is attributed to its ISO46 viscosity and a pour point that is about $-50^{\circ} \mathrm{C}$. Previous research provided a description of the use of polyol esters with high oleic content (Lawate \& Lal 1998).

Studies have also highlighted the importance of boundary lubrication especially during the starting and stopping of a machine when high loads and low speed were applied to the contact surfaces. According to Bushan (2002), a thin layer of lubricant molecule absorbs onto the metal surfaces and provides some protection against wear. It was added so that under boundary lubrication, the physical and chemical interactions of the lubricant with metal surfaces have dominance over the tribological performances. The performance of lubricants under boundary conditions highly relies on their chemical structures. Unsaturation has an inverse relation to the liquidity of the ester or its pour point and at the same time, it has a direct relation to its solubility and chemical reactivity. The higher the unsaturation is, the lower the pour point becomes (higher liquidity) whereas solubility in certain solvents and chemical reactivity increased. However, some unsaturation for low temperature fluidity is required by long chain molecules.
There was no previous study that has been conducted on the lubricity and tribological behaviours on dieters of oleyl alcohol with dicarboxylic acid. Therefore, the current study examined the lubricity and tribological properties of oleyl esters of various long chain dicarboxylic acids $\left(\mathrm{C}_{4}-\mathrm{C}_{12}\right)$.

\section{MATERIALS AND METHODS}

Eight dicarboxylic acids (99\%) (dodecanedioic acid, sebacic acid, azelaic acid, suberic acid, pimelic acid, adipic acid, glutaric acid and succinic acid) and oleoyl alcohol (85\%) of analytical grade were obtained from Fisher Scientific. Other chemicals and reagents were obtained from Aldrich Chemical and were used directly without further purification.

\section{SYNTHESIS OF DIESTER}

The esterification reaction was carried out according to Dean-Stark distillation method. The reaction mixture of dicarboxylic acid and oleoyl alcohol (a mole ratio 1:2) was heated with stirring in an oil bath to desired reaction temperature at $120-130^{\circ} \mathrm{C}$. A catalyst amount of concentrated $\mathrm{H}_{2} \mathrm{SO}_{4}$ ( $2 \%$ of diacid) was slowly introduced into the reaction vessel. The reaction was carried out for about $4 \mathrm{~h}$. Water formed during the reaction was continuously distilled off from the system. The crude reaction product was allowed to cool at room temperature before it was purified and then transferred into a separating funnel. $50 \mathrm{~mL}$ of diethyl ether was added to the funnel followed by three times of $10 \mathrm{~mL}$ of saturated $\mathrm{NaHCO}_{3}$ solution to neutralise the catalytic acid used and unreacted diacid. The saturated sodium chloride solution was added to avoid any emulsion formation. The aqueous layer was decanted and the diethyl ether layer was dried over the sufficient anhydrous $\mathrm{Na}_{2} \mathrm{SO}_{4}$ and the hydrated $\mathrm{Na}_{2} \mathrm{SO}_{4}$ was filtered off. The yield $(\%)$ of the diester product was determined. The final product of diesters was identified by its IR, ${ }^{1} \mathrm{H}-\mathrm{NMR}$, and ${ }^{13} \mathrm{C}$ NMR spectral analyses.

\section{DIESTER CHARACTERISATION}

Fourier transforms infrared spectroscopy (FTIR) and nuclear magnetic resonance (NMR) spectroscopy for proton ${ }^{1} \mathrm{H}$ and ${ }^{13} \mathrm{C}$ were carried out according to Aigbodion and Bakare 2005.

\section{LUBRICITY PROPERTIES}

Flash and pour points, kinematic viscosity, viscosity index and oxidative stability of the diester were determined according to American Society for Testing and Materials (ASTM 2011) standard procedures. Triplicate measurements were made and the average values were reported with the standard deviation $( \pm \mathrm{SD})$. 


\section{TRIBOLOGY AND RHEOLOGY ANALYSIS}

Tribological properties of diester were performed according to ASTM method D4172-94 (ASTM 2011) and discussed based on their Stribeck curves at 40 and $100^{\circ} \mathrm{C}$. The sliding speed was manipulated between $10^{-1}-10^{3} \mathrm{~mm} / \mathrm{s}$ at 40 and $100^{\circ} \mathrm{C}$ (Kalin et al. 2009). Rheological properties of diesters were observed by the rheometer with cone and plate geometry (Coussot et al. 2009). The cone spindle used was CP 25-2 with a diameter of $0.051 \mathrm{~mm}$. The shear rate was manipulated between 0 and $100 \mathrm{~s}^{-1}$ at $25^{\circ} \mathrm{C}$.

\section{RESULTS AND DISCUSSION}

\section{ESTER SYNTHESIS}

Eight different dicarboxylic acids were mixed separately with oleoyl alcohol at (1:2) mole ratio, the mixture put in three necked conical flask contains $50 \mathrm{~mL}$ toluene as medium reaction and connected with Dean-stark apparatus. The esterfication reaction was done as it mentioned in the method section. Figure 1 shows the reaction procedure of dodecanedioic acid and oleyl alcohol to form DOlD. This study was focused on the effect of dicarboxylic acid long chain carbon on the lubricity and tribological properties of diester. The diester yield percentage (\%) is given in Table 1 . The results showed high diester yield $\%$. Those yields of diesters were affected by the electrophilic character of carbonyl carbon of dicarboxylic acids, which increases with the decrease in the long- chain carbon (Romero et al. 2011). Table 1 shows that DOlsuc gave the highest yield percentage at $92 \%$, while DOlD gave the lowest yield percentage at $85 \%$ among all diesters.

\section{ESTER CHARACTERISATION}

All diester chemical structures were verified by FTIR, ${ }^{1} \mathrm{H}$ and ${ }^{13} \mathrm{C}$ NMR spectroscopy. The FT-IR result gave significant peaks of carbonyl stretching vibrations $(\mathrm{C}=\mathrm{O})$ of ester at the range of 1735 to $1745 \mathrm{~cm}^{-1}$ while, the peaks at 3003$3010 \mathrm{~cm}^{-1}$ of $\mathrm{C}=\mathrm{C}$ band were attributed to the unsaturated aliphatic carbons atoms of all diesters. The absence of hydroxyl (OH) stretching vibrations of alcohol (3230-3550 $\left.\mathrm{cm}^{-1}\right)$ and the bonded hydrogen-oxygen stretching of acids $\left(1700-1725 \mathrm{~cm}^{-1}\right)$ in the spectra suggest that the final products of diester were free of any unreacted alcohol and acid impurities. Bands representing $-\mathrm{CH}_{3}$ groups (2850$\left.2980 \mathrm{~cm}^{-1}\right), \mathrm{C}-\mathrm{O}$ stretching vibrations $\left(12441171 \mathrm{~cm}^{-1)}\right.$ and C-O-C $\left(965-1101 \mathrm{~cm}^{-1}\right)$ were clearly visible in the spectra. Figure 2 shows the FTIR spectra of dioleyl dodecanedioate (DOID) as final product and dodecanedioic acid (DA) as raw material. The peak of carbonyl group $(\mathrm{C}=\mathrm{O})$ of $\mathrm{DA}$ appeared at $1700 \mathrm{~cm}^{-1}$, while it was at $1738 \mathrm{~cm}^{-1}$ for DOID.

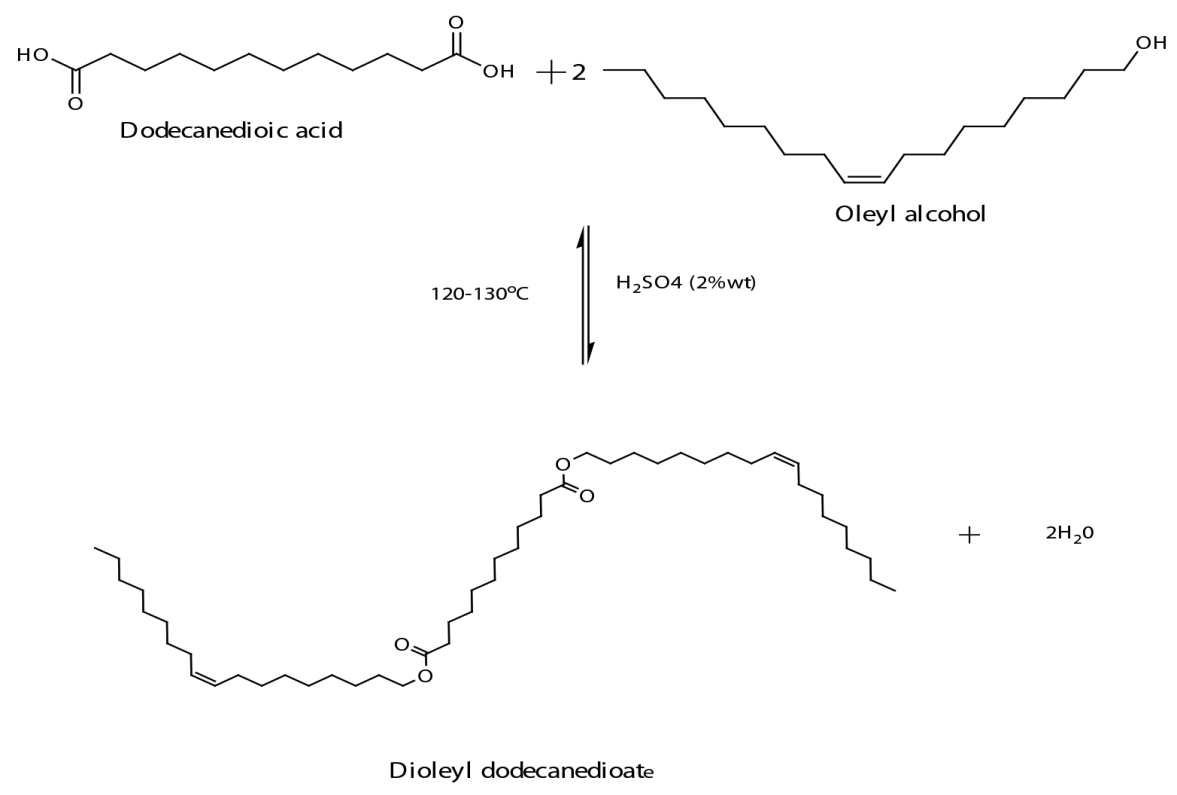

FIGURE 1. Esterification reaction of dodecanedioic acid and oleyl alcohol to form DOID

TABLE 1 . The yield percentage $(\%)$ of diesters

\begin{tabular}{lcccccccc}
\hline Diester & DOID & DOlS & DOlAz & DOlSub & DOIP & DOlA & DOlG & DOlSuc \\
& $18: 12: 18$ & $18: 10: 18$ & $18: 9: 18$ & $18: 8: 18$ & $18: 7: 18$ & $18: 6: 18$ & $18: 5: 18$ & $18: 4: 18$ \\
\hline Yield \% & 85 & 86 & 88 & 89 & 90 & 91 & 92 & 93 \\
\hline
\end{tabular}

Notes: DOID: Dioleyl dodecanedioate, DOlS: Dioleyl sebacate, DOlAz: Dioleyl azelate, DOlSub: Dioleyl suberate, DOlP: Dioleyl pimelate, DOlA: Dioleyl adipate, DOlG: Dioleyl glutarate, DOlSuc: Dioleyl succinat 
Thus, the DA was completely esterified under the reaction conditions. The peak at $3008 \mathrm{~cm}^{-1}$ of $\mathrm{C}=\mathrm{C}$ band was attributed to the unsaturated carbons atoms $(\mathrm{C}=\mathrm{C})$ of DOID.

${ }^{1} \mathrm{H}$ and ${ }^{13} \mathrm{C}$ NMR are the most valuable technique for chemical structure analysis. The ${ }^{1} \mathrm{H}$ and ${ }^{13} \mathrm{C}$ NMR results of all synthesised diesters showed the main ${ }^{1} \mathrm{H}$ and ${ }^{13} \mathrm{C}$ chemical shifts. The ${ }^{1} \mathrm{H}$ chemical shift of $\mathrm{RCOO}-\mathrm{CH}_{2}$ (ester) was clearly appeared at 4.02 to $4.04 \mathrm{ppm}$, while unsaturated aliphatic carbons atoms $(\mathrm{HC}=\mathrm{CH})$ appeared at 5.31- 5.35 ppm. The ${ }^{13} \mathrm{C}$ chemical shift for $(\mathrm{C}=\mathrm{O})$ of ester was appeared at 173-174 ppm, while the ${ }^{13} \mathrm{C}$ chemical shift of unsaturated aliphatic carbons atoms $(\mathbf{C}=\mathrm{C})$ appeared at 129-130 ppm. Those chemical shifts were correspondent to the formation of ester carbonyl (Pavia et al. 2008). The ${ }^{1} \mathrm{H}$ and ${ }^{13} \mathrm{C}$ NMR chemical shifts of DOID and DOIP are presented in details (Table 2).

\section{LUBRICITY PROPERTIES OF DIESTER}

The pour point, flash point, viscosity index and oxidation stability of diester are presented at Table 3 . The lubricant ability in decreasing friction and wear is strongly affected by its viscosity. The viscosity of many esters depend on the temperature where decrease at high temperature (Salimon et al. 2011). Using of lubricants as industrial application depend on their kinematic viscosities at high temperature, for example the kinematic viscosities from 3.8 to $20 \mathrm{cSt}$ at $100^{\circ} \mathrm{C}$ are suitable for engine oil while, from $35.2 \mathrm{cSt}$ and high are demanded for automotive gear (Rudnick 2006). In the current study, the values of kinematic viscosities of diesters were calculated as the ratios of their dynamic viscosity to the density. They showed around 28 to $46 \mathrm{cSt}$ at $40^{\circ} \mathrm{C}$ (Table 3 ), those values made them suitable to be used as hydraulic fluids and engine oil. However, they were low for some other applications such as automotive gear lubricants and grease oil (Bair 2000). Therefore, improvement the kinematic viscosities of esters are needed to mount their applications as lubricants. The viscosity results in Table 3 shows that the viscosity at 40 and $100^{\circ} \mathrm{C}$ increased with the high chain length (number of acid carbons). For example, DOID recorded the highest viscosity values of 46 and $12.8 \mathrm{cSt}$, while DOlSuc showed the lowest values of 28 and $6.2 \mathrm{cSt}$ at 40 and $100^{\circ} \mathrm{C}$, respectively.

The viscosity of diesters increased with the increase in molecular weight and chain length of dicarboxylic acid (Table 3). The viscosity indexes (VIs) values of the diester were dependent on the difference in viscosity at 40 and $100^{\circ} \mathrm{C}$. The VIs of diester in this study was in the range of 155 to 178. Synthesis of esters with high VI can be done by the suitable selection of raw materials that have high molecular weight with linear and branch chemical structures (Buenemann et al. 2003). The pour point is the most important property of any oil used as a lubricant.

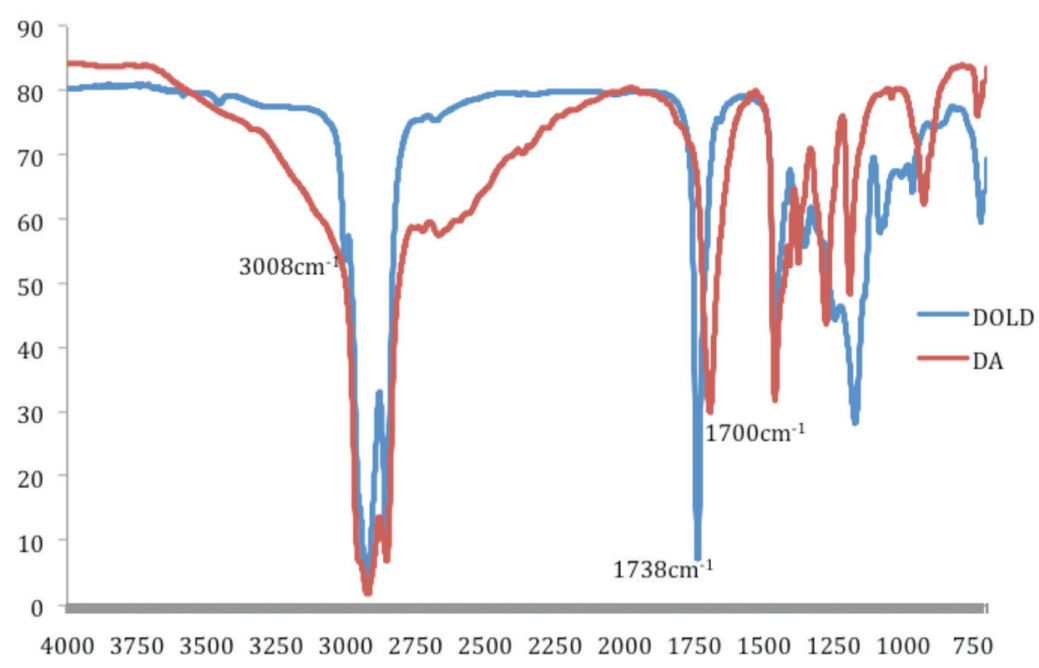

FIGURE 2. Comparison FTIR spectrum of DOID and DA

TABLE 2. The ${ }^{1} \mathrm{H}$ NMR and ${ }^{13} \mathrm{C}$ NMR functional groups of DOIP and DOIS

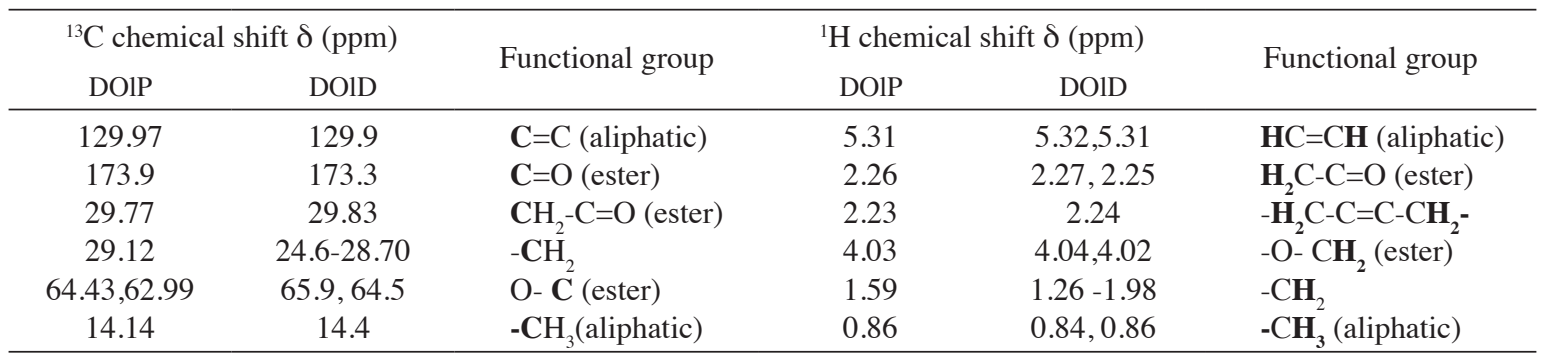


The pour points of diesters in this study are summarised in Table 3. The results indicated that the unsaturated aliphatic carbons atoms $(\mathrm{C}=\mathrm{C})$ in diesters play a significant role in decreasing pour points. But, those pour points increased with the high length of carbon chain of the dicarboxylic acid used. All diesters were in the liquid state at room temperature. The low-temperature fluidity properties of DOlSuc at $-20^{\circ} \mathrm{C}$ were the lowest among all diesters. This decrease was due to the low molecular weight. Despite the high molecular weight of diesters, it gave a good pour point that was attributed to the unsaturated aliphatic carbons atoms. Flash point uses to control the required temperature for transportation and storage of lubricants. Salimon et al. (2010) reported that the appropriate values of flash points for many applications such as in aviation jet engines must be higher than $300^{\circ} \mathrm{C}$. Flash point is indicator for the volatile and flammable materials in the non-volatile material (Bloch 2009).

The results in Table 3 shows that the flash points of the diesters increased with the high molecular weight. The dioleyl dodecanedioate (DOID) indicated remarkable flash point value at $305^{\circ} \mathrm{C}$, which was due to the high molecular weight and long chain acid used, while the lowest point was recorded at $205^{\circ} \mathrm{C}$ for DOlsuc. The flash points of other diesters (e.g. DOlD at $305^{\circ} \mathrm{C}$, DOlS at $290^{\circ} \mathrm{C}$, DOlAz at $275^{\circ} \mathrm{C}$, DOlSub at $257^{\circ} \mathrm{C}$, DOlP at $243^{\circ} \mathrm{C}$, DOlA at $225^{\circ} \mathrm{C}$, DOlG at $210^{\circ} \mathrm{C}$ and DOlSuc at $205^{\circ} \mathrm{C}$ ), in addition to other properties such as low pour point and high viscosity index, made them suitable to be used as lubricants at hightemperature applications. The low of lubricant's volatility is preferred to reduce the need to replenish the lost ester, the increase in viscosity during use and the negative effect on the environment (Bloch 2009; Buenemann et al.
2003). Oxidative stability is very important property for lubricant's quality, especially for long-time use (turbines, transformers, hydraulic and heat transfer units). The rate of oxidation depend on the chemical structure of esters (Murrenhoff 2003). In this study, the diesters were screened to measure their oxidative stability using PDSC through determination of oxidation temperature (OT), which is defined as the temperature at which a rapid increase in the rate of oxidation is observed. High oxidative stability value means more stability to be oxidised (Adhvaryu et al. 2000).

The results from Figure 3 was analysed for the OT. Effects of evaporation indicated by tailing, split peaks and change in baseline were due to loss of sample mass. However, these effects were apparent at temperatures higher than the initial oxidation peak. Moreover, these effects did not interfere with the measurement of the OT values by extrapolation of peak onset temperatures. The OT was calculated from a plot of heat flow $(\mathrm{W} / \mathrm{g})$ versus temperature generated by the sample upon degradation. Murrenhoff (2003) stated that the chemical structure of diester has significant effect on the rates of oxidation. Kubouchi et al. (2002) reported that the long-chain carbon of the acids and alcohols used in the esterfication increases the oxidative stability. Table 3 and Figure 3 show the values of oxidative stability as (ОT) of all diester in this study. The DOID (OT $183^{\circ} \mathrm{C}$ ) indicated the highest oxidative stability among all diesters due to the increase in the molecular weight. In general, the oxidative stability of all diesters was slightly low because of the presence of unsaturation $(\mathrm{C}=\mathrm{C})$. Moser (2009) stated that the effect of unsaturated group on the oxidative stability increases with the high number of double bond. For example, the mono-unsaturated as methyl

TABLE 3 . The lubricity properties of synthesised diesters

\begin{tabular}{|c|c|c|c|c|c|c|}
\hline Diester & $\mathrm{KV}$ at $40^{\circ} \mathrm{C}$ & $\mathrm{KV}$ at $100^{\circ} \mathrm{C}$ & $\mathrm{VI}$ & OT $\left({ }^{\circ} \mathrm{C}\right)$ & F.P $\left({ }^{\circ} \mathrm{C}\right)$ & P.P $\left({ }^{\circ} \mathrm{C}\right)$ \\
\hline $\begin{array}{l}\text { DOID } \\
18: 12: 18\end{array}$ & 45.99 & 12.8 & 168 & $183 \pm 2$ & $305 \pm 5$ & $20 \pm 2$ \\
\hline $\begin{array}{l}\text { DOIS } \\
18: 10: 18\end{array}$ & 44.66 & 11.8 & 167 & $175 \pm 2$ & $290 \pm 5$ & $15 \pm 2$ \\
\hline $\begin{array}{l}\text { DOlAz } \\
\text { 18:9:18 }\end{array}$ & 38.55 & 9.9 & 165 & $173 \pm 2$ & $275 \pm 5$ & $10 \pm 2$ \\
\hline $\begin{array}{l}\text { DOlSub } \\
18: 8: 18\end{array}$ & 33.23 & 9.6 & 178 & $172 \pm 2$ & $257 \pm 3$ & $7 \pm 2$ \\
\hline $\begin{array}{l}\text { DOIP } \\
18: 7: 18\end{array}$ & 32.52 & 9.2 & 175 & $170 \pm 2$ & $243 \pm 6$ & $-10 \pm 1$ \\
\hline $\begin{array}{l}\text { DOlA } \\
18: 6: 18\end{array}$ & 31.04 & 8.8 & 176 & $169 \pm 1$ & $225 \pm 5$ & $-12 \pm 3$ \\
\hline $\begin{array}{l}\text { DOlG } \\
18: 5: 18\end{array}$ & 30.49 & 7.8 & 171 & $166 \pm 1$ & $210 \pm 5$ & $-16 \pm 1$ \\
\hline $\begin{array}{l}\text { DOlSuc } \\
18: 4: 18\end{array}$ & 28.28 & 6.2 & 155 & $151 \pm 3$ & $205 \pm 5$ & $-20 \pm 2$ \\
\hline $\mathrm{PAO}$ & 33 & 6.0 & 140 & 167 & 190 & -57 \\
\hline
\end{tabular}

Notes: VI: viscosity index, KV: Kinematic Viscosity, OT: oxidative temperature. F.P: flash point, P.P: poure point, values are mean \pm SD of triplicate determinations. PAO: polyalphaolefin as real lubricant (Rudnick 2006). 


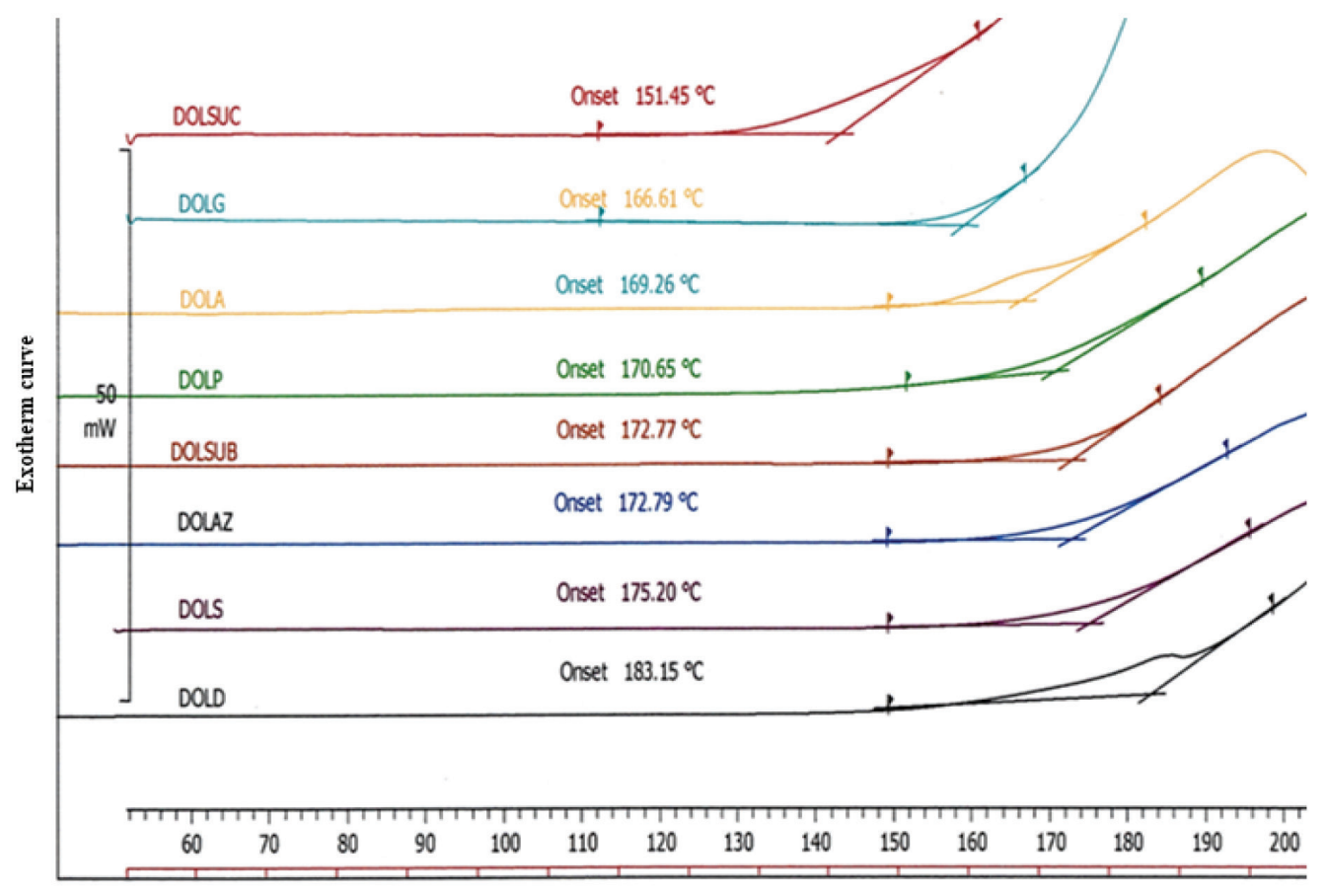

Oxidative temperature (OT)

FIGURE 3. PDSC exotherm curve of oxidation temperature (OT) for the diesters

oleate $\left(\mathrm{OT} 174.9^{\circ} \mathrm{C}\right)$ is more stable than di-unsaturated as methyl linoleate (OT $142.6^{\circ} \mathrm{C}$ ), while the general rule in the saturated esters, the ease of oxidation of $\mathrm{C}-\mathrm{H}$ bonds follows the following order: $-\mathrm{CH} 3$ (most stable) $>-\mathrm{CH} 2-$ $>\mathrm{CH}-$ (most reactive) (Rudnick 2006).

\section{TRIBOLOGY AND RHEOLOGY OF DIESTERS}

Boundary lubrication is defined as a condition where the solid surfaces are so close together that surface interaction between single or multimolecular films of lubricants and the solid asperities dominates the contact (Bhushan 2013). The oleate diesters in this study have polar structures. This polar structure is able to form an effective boundary layer. Durak et al. (2004) state that vegetable oils exhibit good lubricity because they contain organic straight-chain compounds with polar end groups. These polar end groups can be adsorbed on a metallic surface, which decreases or suppresses the surface energy and causes a reduction of the friction coefficient. Salimon et al. (2012) state that the long fatty acid chain and the presence of polar groups in the structure of plant oil makes it amphiphilic in nature, therefore allows it to be used as both boundary and hydrodynamic biolubricants. The results of the COF for the diesters with varying chemical structure are presented in Table 4. For the tests at different temperature (40 and $100^{\circ} \mathrm{C}$ ), the $\mathrm{COF}$ of the diesters was higher at $100^{\circ} \mathrm{C}$ than $40^{\circ} \mathrm{C}$ due to the decrease in the viscosity of the diesters. The high value of COF of DOISuc was attributed to the low molecular weight and the viscosity. The COF increased with low molecular weight and viscosity of diesters and vice versa. Generally, all of the diesters recorded low COF below than 0.5 at 40 and $100^{\circ} \mathrm{C}$. These results indicated that all products had a good quality of their tribological properties even when the temperature was increased. The results showed that all the diesters were boundary lubricants with low COF at 40 and $100^{\circ} \mathrm{C}$.

Figure 4 shows the rheology analysis results of diester's (DO1Suc and DOID) shear stress vs. shear rate plot. From the plot, fluids can be decided as Newtonian or nonNewtonian fluids. Classification of fluids as Newtonian and non-Newtonian depends on their viscosity by increasing shear rate, where the constant viscosity is Newtonian, while nu-constant viscosity is non Newtonian (Batchelor 2000). Based on Figure 4, DOlSuc was identified as a nonNewtonian fluid while DOID was a Newtonian fluid. The rest of the diesters namely DOIS, DOlAz, DOISub, DOIP, and DOlG were identified as non-Newtonian fluids.

TABLE 4. Tribological properties of the diesters

\begin{tabular}{cccccccccc}
\hline \multicolumn{2}{c}{ Diester } & DOlD & DOlS & DOlAz & DOlSub & DOlP & DOlA & DOlG & DOlSuc \\
\hline \multirow{2}{*}{$\mathrm{COF}$} & $40^{\circ} \mathrm{C}$ & 0.15 & 0.16 & 0.17 & 0.18 & 0.19 & 0.20 & 0.22 & 0.25 \\
& $100^{\circ} \mathrm{C}$ & 0.19 & 0.20 & 0.21 & 0.23 & 0.25 & 0.27 & 0.30 & 0.32 \\
\hline
\end{tabular}



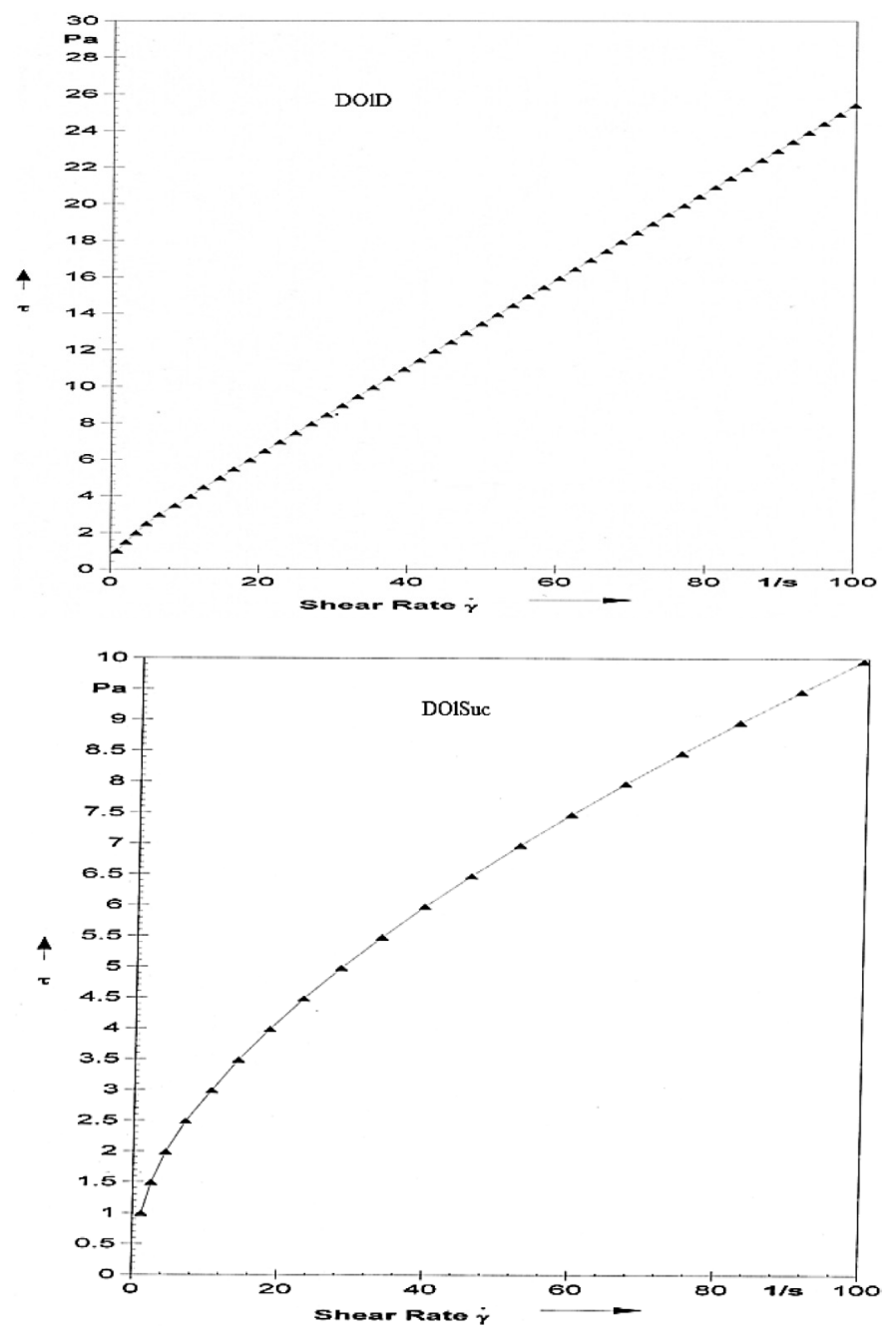

FIGURE 4. Shear stress $(\tau)$ vs. shear rate $(\gamma)$ plots of DOlD and DOlSuc respectively at $25^{\circ} \mathrm{C}$

\section{CONCLUSION}

This study showed that the esterification of oleyl alcohol and dicarboxylic acid produced high yield of diester with good tribological and lubrication properties. Based on the results, it is possible to use the synthesised diesters as lubricants for both cold and warm climates without any additives. The results also showed that, despite the unsaturation $(\mathrm{C}=\mathrm{C})$ of diester, they had a high oxidative stability. This study suggests that the improvement of the lubricity properties (e.g. the pour point at low temperatures and oxidative stability and flash point at high temperatures) of the synthesised diesters can be investigated by the epoxidation followed by oxirane ring opening reactions.

\section{ACKNOWLEDGEMENTS}

We would like to thank Universiti Kebangsaan Malaysia (UKM) for the project funding under University Research Grants No. DPP-2014-058, GGPM-2014-033 and the School of Chemical Science and Food Technology, Faculty of Science and Technology, Universiti Kebangsaan Malaysia for their support and encouragement.
REFERENCES

Adhvaryu, A., Erhan, S.Z., Liu, Z.S. \& Perez, J.M. 2000. Oxidation kinetics studies of unmodified and genetically modified vegetable oils using pressurised differential scanning calorimetry and nuclear magnetic resonance spectroscopy. Thermochimica Acta 364(1): 87-97.

Aigbodion, A.I. \& Bakare, I.O. 2005. Rubber seed oil quality assessment and authentication. Journal of American Oil Chemical Society 82: 465-469.

ASTM 2011. Standard Test Method for Wear Preventive Characteristics of Lubricating Fluid (Four-ball Method). West Conshohocken, PA (USA): ASTM.

Bair, S. 2000. Pressure-viscosity behavior of lubricants to $1.4 \mathrm{GPa}$ and its relation to EHD traction. Tribology Transaction 43(1): 91-99.

Batchelor, G. 2000. An Introduction to Fluid Mechanics. Cambridge: Cambridge University Press.

Bhushan, B. 2013. Boundary Lubrication and Lubricants. In Principles and Applications of Tribology. New York: John Wiley \& Sons, Ltd.

Bloch, H.P. 2009. Practical Lubrication for Industrial Facilities. Georgia: The Fairmont Press Inc.

Boyde, S. 2005. Hydrolytic stability of synthetic ester lubricants. Lubrication Sciences 16(4): 297-312. 
Buenemann, T.F., Boyde, S., Randles, S. \& Thompson, I. 2003. Synthetic lubricants non aqueous. Fuels and Lubricants Handbook: Technology, Properties, Performance, and Testing., West Conshohocken, PA: ASTM International. Chapter 10, pp. 249-266.

Bushan, B. 2002. Introduction to Tribology. New York: John Wiley \& Sons Inc. p 533

Coussot, P., Tocquer, L., Lanos, C. \& Ovarlez, G. 2009. Macroscopic vs local rheology of yield stress fluids. Journal of Non-Newtonian Fluid Mechanics 158: 85-90.

Durak, E., Çetinkaya, M., Yeinigün, B. \& Karaosmanoğlu, F. 2004. Effects of sunflower oil added to base oil on the friction coefficient of statically loaded journal bearings. Journal of Synthetic Lubrication 21(3): 207-222.

El-Magly, L.A., Nasr, E.S. \& El-Samonoudy, M.S. 1990. Optimal preparation conditions for some diester-based synthetic lubricants. Journal of Synthetic Lubrication 7(2): 89-103.

Fatemi, S.H. \& Hammond, E.G. 1980. Analysis of oleate, linoleate and linoleate hydroperoxides in oxidised ester mixtures. Lipids 15: 379-385.

Kalin, M., Velkavrh, I. \& Vizintin, J. 2009. The Stribeck curve and lubrication design for non-fully wetted surfaces. Wear 267: 1232-1240.

Kubouchi, H., Kai, H., Miyashita, K. \& Matsuda, K. 2002. Effects of emulsifiers on the oxidative stability of soybean oil TAG in emulsions. Journal of American Oil Chemical Society 79: 567-570.

Lawate, S.S. \& Lal, K. 1998. High oleic polyol esters, compositions and lubricants, functional fluids and greases containing the same. U.S. Patent 5773391.

Lee, P.J., Robert, L. \& Prasad, S.V. 2003. Novel microemulsion enhancer formulation for simultaneous transdermal delivery of hydrophilic and hydrophobic drugs. Pharmaceutical Research 20(2): 264-269.

Moser, B.R. 2009. Comparative oxidative stability of fatty acid alkyl esters by accelerated methods. Journal of the American Oil Chemists' Society 86: 699-706.

Murrenhoff, H.R.A. 2003. Environmentally friendly oils. Fuels and Lubricants Handbook: Technology, Properties, Performance, and Testing, edited by Totten, G.E., West Conshohocken, PA: ASTM International. Chapter 11. pp. 267-295.
Pavia, D.L., Lampman, G.M., Kriz, G.S. \& Vyvyan, J.R. 2008 Introduction to Spectroscopy 4th ed. Belmont: Brooks/Cole, Cengage Learning.

Romero, M.D., Gomez, J.M. \& Diaz-suelto, B.G. 2011 . A study of the influence of alcohols in the synthesis of short chain esters. Chemical Engineering Transactions 24: 37-42.

Rudnick, L.R. 2006. Synthetics, Mineral Oils, and Bio-based Lubricants: Chemistry and Technology. New York: CRC/ Taylor \& Francis Group. Chapter 21. pp. 22-31.

Salimon, J., Salih, N. \& Yousif, E. 2012. Triester derivatives of oleic acid: The effect of chemical structure on low temperature, thermo-oxidation and tribological properties. Industrial Crops and Products 38: 107-114.

Salimon, J., Salih, N. \& Yousif, E. 2011. Synthetic biolubricant basestocks from epoxidised ricinoleic acid: Improved low temperature properties. Chemistry in Industry 60(3): 127-134.

Salimon, J., Salih, N. \& Yousif, E. 2010. Chemically modified biolubricant basestocks from epoxidised oleic acid: Improved low temperature properties and oxidative stability. Journal of Saudi Chemical Society 15: 195-201.

Sudimack, J.J., Wenjin, G., Werner, T. \& Robert, J.L. 2002 . A novel $\mathrm{pH}$-sensitive liposome formulation containing oleyl alcohol. Biochimica et Biophysica Acta (BBA)-Biomembranes 1564(1): 31-37.

School of Chemical Sciences and Food Technology Faculty of Science and Technology

Universiti Kebangsaan Malaysia

43600 Bangi, Selangor Darul Ehsan

Malaysia

*Corresponding author; email: jumat@ukm.edu.my

Received: 23 April 2014

Accepted: 26 September 2014 